\title{
THE INVASIVENESS OF SOLIDAGO CANADENSIS IN THE SANCTUARY «PRILEPSKY» (BELARUS)
}

\author{
Dmitriy V. Dubovik ${ }^{1, *}$, Arkadiy N. Skuratovich ${ }^{1}$, Daniel Miller ${ }^{2}$, \\ Elena V. Spiridovich ${ }^{3}$, Yuri N. Gorbunov ${ }^{4}$, Yulia K. Vinogradova, ${ }^{4, * *}$ \\ ${ }^{1}$ Institute of Experimental Botany of the National Academy of Sciences of Belarus, Belarus \\ *e-mail:dvdubovik73@gmail.com \\ ${ }^{2}$ University of Minnesota Landscape Arboretum, USA \\ e-mail:mille414@umn.edu \\ ${ }^{3}$ Central Botanical Garden of the National Academy of Sciences of Belarus, Belarus \\ e-mail: E.Spiridovich@cbg.org.by \\ ${ }^{4}$ Main Botanical Garden of RAS, Russia \\ **e-mail: gbsad@mail.ru
}

Received: 30.11.2018. Revised: 12.02.2019. Accepted: 13.02.2019.

\begin{abstract}
Protected Areas provide a valuable source of information on the effects of invasive alien species on biodiversity and ecosystem functioning as well as the dynamics of invasions. Solidago canadensis is an extremely aggressive alien species. It is included into the world's 100 most invasive plant species. Our study aimed to monitor the invasiveness of S. canadensis in the Sanctuary «Prilepsky» in Minsk district. The article contains a brief description of the introduction of Solidago canadensis in Europe and more detailed in Belarus. The parameters characterising its invasiveness (average shoot length, foliage projective cover, average number of vegetative shoots, average number of generative shoots of $S$. canadensis and the average number of associated species per study plot) have been measured in three plant communities of the Sanctuary «Prilepsky» (Minsk district, Belarus) in 2016 and 2018. We noted that the invasiveness of $S$. canadensis is linked to the amount of sunlight received by ecotope. The proposed control measures include the afforestation of the open parts of the Sanctuary «Prilepsky» using native tree species, multiple mowings, and destroying the plants directly at the areas of most concern by volunteers.
\end{abstract}

Key words: biodiversity, Canadian goldenrod, invasion, plant community, Protected Area

\section{Introduction}

Biological invasions in Protected Areas (PAs) are a global problem. Protected areas are intended to provide native biodiversity and habitats with a refuge against the impacts of global change, particularly acting as natural filters against biological invasions. In practice, however, it is unknown how effective PAs will be in shielding native species from invasions under projected climate change (Gallardo et al., 2017). When nature reserves were first established, no one could foresee that the largest threat to biodiversity conservation in protected areas would not be the hunters or land users but the inexorable spread of alien species (Foxcroft et al., 2013). In the past decades, data has surfaced that no ecosystem, including strictly protected areas, is free from invasive species (Nagendra et al., 2013). For example, in the Grand Teton National Park (Rocky Mountains, USA), there are more than 1000 species of vascular plants, 26 of which are considered invasive (Wyoming Weed and Pest Council, 2018). There are 1870 plant species growing in Yellow- stone National Park, 82 of which are invasive (Tilt, 2015). The flora of Glacier National Park includes 1132 plant species, 126 of which are alien, and 27 are classified as invasive (Belt et al., 2011). A similar pressure through invasive species was observed in South America, in the Andes of South-Central Chile, in Villiarrica and Huerquehue National Parks. Thirty nine invasive species have been reported, with $85 \%$ of them native to Eurasia (Pauchard \& Alaback, 2004). There are 231 alien plant species registered in the Kruger National Park in South Africa with 79 of them being dominant in the region (Foxcroft et al., 2007).

The growing recognition of the adverse impact of biological invasions has lead to the establishment of the World Committee for Biological Invasions in the framework of the International Union for Conservation of Nature Resources. Protected Areas provide a valuable source of information on the effects of invasive alien species (IAS) on biodiversity and ecosystem functioning as well as the dynamics of invasions, as in general there is a much deeper knowledge base for 
protected areas than for the rest of the territory (Monaco \& Genovesi, 2014).

The consequences of the introduction of alien plants differ by the degree of their impact on the natural communities. But in general, no dissemination of alien species should be permitted to the protected areas, as their first priority is the conservation of native biodiversity and the functioning of native ecosystems. «Letting nature take its course» is not a strategy that can be used for invasive alien species and active management of this issue is therefore fundamental (Monaco \& Genovesi, 2014). That is why, to develop protected area management strategy, it is essential to consider the issue of preventing the introduction of new alien species to the area. It is absurd that in some regions it is still allowed to grow alien plant species along the border of protected areas or, on the other hand, forbidden to destroy any plants, even invasive species (Vinogradova, 2018).

The invasion of Solidago canadensis L. in Protected Areas is of special concern, where by definition only the native species are to be preserved. The expansion of invasive plant species, including $S$. canadensis in such Sanctuaries of Belarus as Volmyansky, Stiklevo, Yukhnovsky, Pekalinsky is a great problem.

The $S$. canadensis s. 1. complex (= Solidago subsect. Triplinerviae (Torr. \& A. Gray) G.L. Nesom) is very aggressive and taxonomically variable, and its scope is debatable not only in the secondary distribution area, but also in its native range in North America (Semple \& Cook, 2006; Semple et al., 2013, 2015). According to recently prevailed data, the more frequently naturalised species in $\mathrm{Eu}-$ rope is $S$. altissima L. and the less frequent species is $S$. canadensis L. (Weber, 1998). However, while according to other sources, the diploid S. canadensis $\mathrm{s} . \mathrm{str} .(2 \mathrm{n}=18)$ naturalised in Europe, while the hexaploid $(2 n=54) S$. altissima has only been observed in Belgium once (Verloove et al., 2017).

Solidago canadensis is described from Virginia and Canada; lectotype: Herb. Linn. - 998.2 (LINN). The typical specimen from the Linnaean Herbarium has small heads in a spreading panicle and upper leaves with sparse teeth spaced apart; there are no lower leaves or rhizomes.

Solidago altissima L. is different from $S$. canadensis in having longer shoots, broader leaves and a much later flowering time - in Belgium, it begins to bloom in October (Verloove et al., 2017). Plants with similar characteristics have also become widespread in Eastern Asia. According to our observations, in Japan they have not any buds in September yet. Thus, highly pubescent plants, which were previously considered as belonging to $S$. altissima, must be classified as $S$. canadensis var. hargeri Fernald (Verloove et al., 2017).

According to herbarium data [MSK, MSKU, MSKH], the following taxa occur in Belarus: $S$. canadensis var. canadensis and $S$. canadensis var. hargeri. The first taxon has less pubescent stems than the second one. However, apparently these «varieties» are nothing more than non-heritable morphotypes growing in different habitats in terms of the moisture content. At least, as a matter of practice, it is not always possible to use this diagnostic feature. For example, the portions of rhizomes collected from virtually glabrous parent plants produced offspring with pubescent stems and leaves at the testing plot of the Main Botanic Garden of RAS. However, $S$. canadensis is actually quite polymorphic in Belarus (Dubovik \& Saulov, 2017). There are specimens with narrow-lanceolate $(12 \times 1 \mathrm{~cm})$, and lanceolate leaves $(10 \times 3 \mathrm{~cm})$. Sometimes, there is variation in the degree of pubescence of the upper side of the leaf, and the serration of the leaf margin. The shape of the inflorescence is quite variable too - from a narrower one (almost egg-like) to a spreading panicle with the branches drooping at the ends. Even within one coenosis there is a wide variation between plants observed in terms of the inflorescence shapes and time of flowering. A shorter morphotype with a compress panicle near Minsk usually begins to bloom (in the first ten days of July, and most plants are in bloom by 15 July). A taller morphotype with a spreading panicle usually begins to bloom later (more frequently at the beginning of August) (Dubovik \& Saulov, 2017). Thus, different plants of the same population may begin to bloom 15 days apart from one another. This seems to be caused both by environmental factors (degree of shade, soil conditions, etc.), and the genotypic variation of the species (Vinogradova \& Galkina, 2019).

At two localities in Belarus, the hybrid of the native $(S$. virgaurea $L$.) and alien $(S$. canadensis) species was discovered $-S . \times$ niederederi Khek. The hybrid is distinct in their intermediate morphological characteristics. It was collected in mixed populations of parental species at the following disturbed areas: 1) in Minsk (Chelyuskintsev Park, 1980, D. Tretyakov, MSK); 2) in the village Šlyki in Vitebsk District (Dubovik \& Saulov, 2017, MSK). 


\section{History of Solidago canadensis invasion in Europe and Belarus}

The history of the introduction of Solidago $\mathrm{Ca}$ nadensis in Europe began in 1645 in England where it was used as a garden plant. The lag phase of the species was approximately 160 years. Solidago canadensis as an established non-native plant was observed in Latvia in 1805, in the European part of Russia in 1855, and in Poland in 1872 (NOBANIS, 2018).

In 1925-1936, European gardeners became enthusiastic about this plant (Weber, 2001). For example, there is the well-known firm G. Arends in Germany (Arends, 1951; Dubovik \& Saulov, 2017), which was involved in breeding numerous Solidago varieties and distributed them all across Europe. Possibly, some varieties were hybrids with the species closely related to $S$. canadensis. For example, there is a hypothesis (Sell \& Murrell, 2006), that some of the plants established in the wild in the UK are the hybrids with $S$. gigantea Ait. or S. rugosa Mill.

In Belarus, $S$. canadensis was first mentioned in the catalogue of introduced plants at the Bolshie Letsy manor in Vitebsk District in 1915 (Index Plantarum, 1915). Later, in 1934, it was registered at a shrubby peatland near Niasviž. But this mention is doubtful and is not confirmed by herbarium data. One may assume that until the first half of the $20^{\text {th }}$ century $S$. canadensis was quite rare in Belarus (Dubovik \& Saulov, 2017).

The species has been cultivated at the Central Botanical Garden of the National Academy of Sciences of Belarus since 1947. Seeds have been received from Sweden, the Czech Republic, Ukraine, Russia, and Yugoslavia (The Main Book, 1948; Dubovik \& Saulov, 2017). And during the same years its varieties were introduced here. In 1954 and 1955, N. Kozlovskaya collected a morphotype of $S$. canadensis with a narrow panicle and a reddish stem (MSK) at the Central Botanical Garden. According to the Flora of Belarus (Shishkin, 1959), «the species occurs quite frequently, it is cultivated, and sometimes goes wild». In 1960-1970, the species was extensively cultivated in nearby flower beds and country house garden plots in and around Minsk as a decorative plant. The Central Botanical Garden was the source of the species' diaspores (Dubovik \& Saulov, 2017).

Since 1973, Solidago canadensis has begun to go wild, escaping from country house garden plots in Smaliavičy District (Dubovik \& Saulov, 2017). And in 1975, it was collected as a naturalised plant in the village Sucharukija in the vicinity of Minsk
(MSK). During the same period, S. canadensis was mentioned as «a plant frequently occurring in the gardens, parks, and vegetable gardens» (Kozlovskaya, 1978). Thus, garden «escape» can be considered as the invasion pathway of $S$. canadensis in the region. In 1979, Vynaev reported the species as a rare ruderal plant in Homiel, and in 1982 as a fully naturalised species along the Minsk-Sciapianka branch railway line. It grows on the slopes of the railway and on highway embankments, at forest roadside shelter-belts, in forest edges, in roadside areas, in thinned pine and birch forests adjoining the railway. Finally, the Canadian goldenrod could be found occasionally as single plants or in small groups of individuals. Thus, in 1970-1980, S. canadensis was fully naturalised in Belarus (MSK, MSKU, MSKH).

During the country house building boom in 1990-1994, amateur flower gardeners extensively used vegetative propagation for the reproduction of this late-flowering hardy species. It is also broadly cultivated on cemeteries, from where it has spread on a massive scale. An additional reason for its explosive expansion was the increase of the area of barren land (abandoned hobby farm construction sites, plots following unauthorised cultivation near populated localities, and others).

At present, the species occurs across the entire country very frequently. In some districts of Minsk Oblast (Smaliavičy, Minsk, Lahoisk, Dziaržynsk, Maladziečna, Puchavičy, Červień, etc.) it is a real threat for the native flora, where Solidago canadensis invades native phytocoenoses. Solidago canadensis is still rare in the Belarusian Polesie and Poozerie regions. However, its inevitable expansion is observed there too. It is one of the most dangerous invasive species in the flora of Belarus (Dubovik et al., 2013).

Our study aimed to monitor the invasiveness of $S$. canadensis in the experimental plots at the Sanctuary «Prilepsky» in Minsk district of Belarus. This is where the control measures against $S$. canadensis have been taken according to our recommendations.

\section{Material and Methods}

From 2016 to 2018, we surveyed a site at the boundary of the Sanctuary «Prilepsky», where the invasion of the species occurred. The site is located in the vicinity of Zialiony Bor (Minsk district), $12 \mathrm{~km}$ north of Minsk (Fig. 1): $54^{\circ} 00^{\prime} 56 \mathrm{~N}$, $27^{\circ} 41^{\prime} 06^{\prime \prime} \mathrm{E}$. This is along the edge of the mossMyrtillus subor (mixed forest on transitional, relatively poor soils), at the regenerating clear cutting. The soil is sod-podzol loam. 


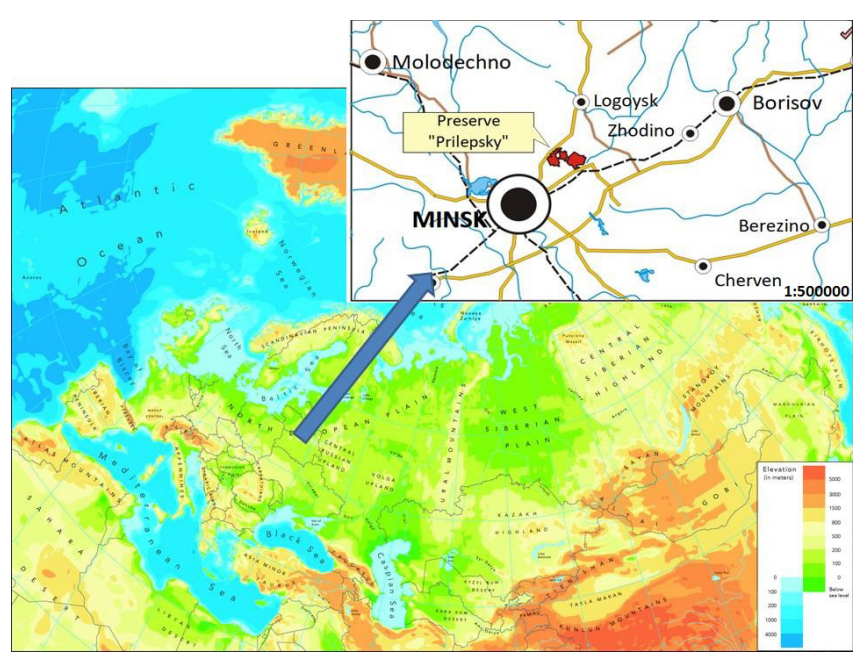

Fig. 1. Location of the Sanctuary «Prilepsky» (Belarus).

The study sites included the following plant communities: a) Lupinus polyphyllus Lindl. + Festuca rubra L. + Solidago canadensis community, b) Elymus repens (L.) Gould + forbs + Solidago canadensis community, and c) Solidago canadensis + Pteridium aquilinum (L.) Kuhn community. We established plots with a size of $1 \times 1 \mathrm{~m}$ in each community in three replications. Five parameters were measured per study plot: the average length of $S$. canadensis shoots, projective plant cover, average number of vegetative shoots, average number of reproductive shoots, and average number of associated species. Basic statistical analyses were performed using PAST 3.0. Hierarchical clustering of similarity between communities was calculated on the basis of UPGMA algorithm and similarity index by Euclidean distance. All species of vascular plants were recorded, their covers were estimated and used as importance values for calculating the Shannon diversity index of similarity between plots in 2016 and 2018.

\section{Results and Discussion}

To visualise the results, we have used radar charts, which represent the five parameters under study (Fig. 2). The mosaic vegetation is the cause of a considerable variability in the population characteristics of $S$. canadensis.

Plot a (Lupinus polyphyllus + Festuca rubra + Solidago canadensis community). Over the three years of observation the average height of $S$. canadensis had increased from 130 to $140 \mathrm{~cm}$, the average projective cover statistically significantly declined from $80 \%$ to $70 \%(p<0.01)$, the average number of reproductive shoots per plot reduced from 80 to 38 . And the variation of the average number of vegetative shoots (4-6) was not statistically significant. The number of associated species reduced from 16 to 8 .

Plot b (Elymus repens + motley grasses + Solidago canadensis community). The average height of $S$. canadensis had decreased from $160 \mathrm{~cm}$ to 150 $\mathrm{cm}$. The average projective cover declined from $97 \%$ to $70 \%$. The average number of reproductive shoots at the site reduced from 60 to 45 , while the number of vegetative shoots, on the contrary, increased from 2 to 19 . The number of associated species increased from 6 to 13.

Plot c (Solidago canadensis + Pteridium aquilinum community). The average height of $S$. canadensis varied very slightly from year to year between $165 \mathrm{~cm}$ and $170 \mathrm{~cm}$. The average projective cover slightly declined from $80 \%$ to $75 \%$. The average number of reproductive shoots per plot increased from 60 to 76. And the number of vegetative shoots also increased from 0 to 14 . The number of associated species decreased from 10 to 8 .

Depending on the measures taken to control the invasion of alien species, plant association structure, the amount of sunlight received by an ecotope, the characteristics of a $S$. canadensis population, and the composition of associated species changed considerably (Table 1; Appendix 1). In general, 37 plant species in total were registered on all plots together.

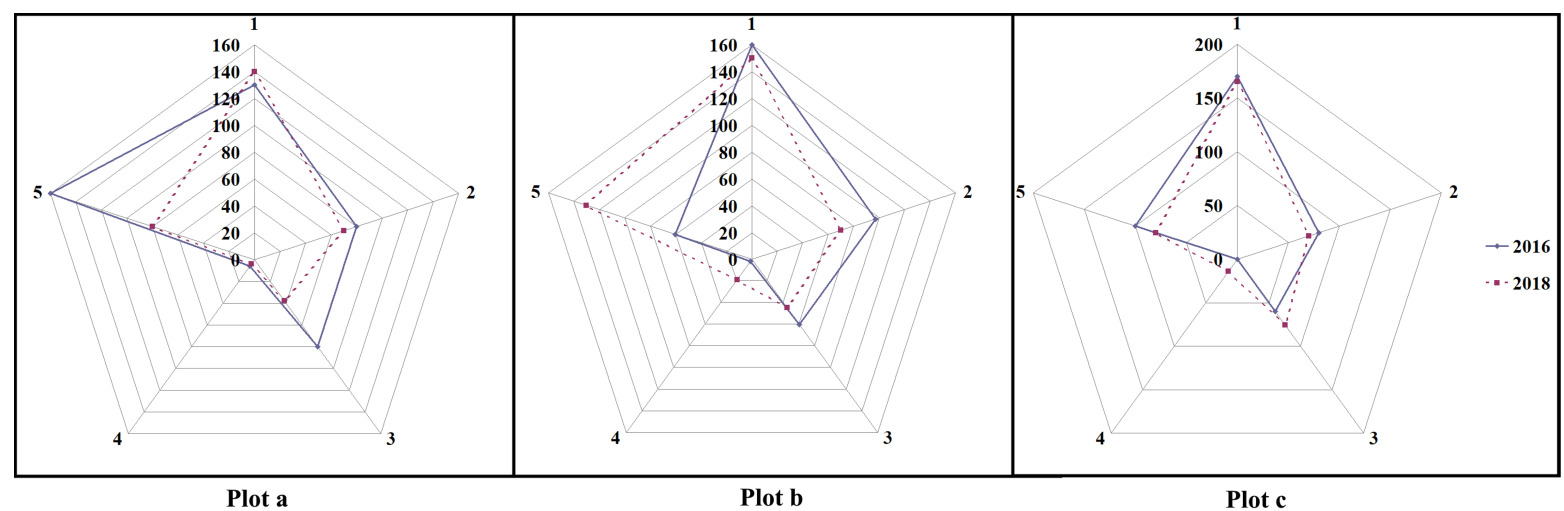

Fig. 2. Population characteristics of $S$. canadensis in various communities of the Sanctuary «Prilepsky». Designations: 1 - average height, cm; 2 - projective cover, $\% ; 3$ - number of generative shoots; units; 4 - number of vegetative shoots, units; 5 - average number of associated species, units. Plant communities: a) Lupinus polyphyllus + Festuca rubra + Solidago canadensis community; b) Elymus repens + motley grasses + Solidago canadensis community; c) Solidago canadensis + Pteridium aquilinum community. 
Table. Changes in the characteristics of Solidago canadensis population in 2016 and 2018

\begin{tabular}{|c|c|c|c|c|c|c|c|c|c|c|}
\hline \multirow[t]{2}{*}{ Plots } & \multicolumn{2}{|c|}{$\begin{array}{c}\text { average height of generative } \\
\text { individuals }(\mathrm{cm})\end{array}$} & \multicolumn{2}{|c|}{ average projective cover $(\%)$} & \multicolumn{2}{|c|}{$\begin{array}{l}\text { number of reproductive } \\
\text { shoots }\end{array}$} & \multicolumn{2}{|c|}{$\begin{array}{l}\text { number of vegetative } \\
\text { shoots }\end{array}$} & \multicolumn{2}{|c|}{$\begin{array}{c}\text { number of } \\
\text { associated species }\end{array}$} \\
\hline & 2016 & 2018 & 2016 & 2018 & 2016 & 2018 & 2016 & 2018 & 2016 & 2018 \\
\hline \multirow[b]{2}{*}{$\mathrm{a}$} & 130 & 140 & 80 & 70 & 80 & 38 & 6 & 6 & 16 & 8 \\
\hline & \multicolumn{2}{|c|}{$+8 \%$} & \multicolumn{2}{|c|}{$-10 \%$} & \multicolumn{2}{|c|}{$-53 \%$} & \multicolumn{2}{|c|}{$0 \%$} & \multicolumn{2}{|c|}{$-50 \%$} \\
\hline \multirow{2}{*}{ b } & 160 & 150 & 97 & 70 & 60 & 45 & 2 & 19 & 6 & 13 \\
\hline & \multicolumn{2}{|c|}{$-6 \%$} & \multicolumn{2}{|c|}{$-27 \%$} & \multicolumn{2}{|c|}{$-25 \%$} & \multicolumn{2}{|c|}{$+850 \%$} & \multicolumn{2}{|c|}{$+116 \%$} \\
\hline \multirow{2}{*}{$\mathrm{c}$} & 170 & 165 & 80 & 70 & 60 & 76 & 0 & 14 & 10 & 8 \\
\hline & \multicolumn{2}{|c|}{$-3 \%$} & \multicolumn{2}{|c|}{$-10 \%$} & \multicolumn{2}{|c|}{$+27 \%$} & \multicolumn{2}{|c|}{$+1300 \%$} & \multicolumn{2}{|c|}{$-20 \%$} \\
\hline
\end{tabular}

Note: + increase of the parameter (at \%), - decrease of the parameter (at \%).

From 2016 to 2018 the presence of another North American invasive species Lupinus polyphyllus was also noted on plot a. This species is more competitive than $S$. canadensis due to the release of nitrogen into the soil (Scherer-Lorenzen et al., 2008). That is why, despite the decrease in the projective cover and number of $S$. canadensis reproductive shoots, the number of associated native species has still declined considerably as a result of joint impact of both invasive species.

At plot b, birch (Betula pubescens Ehrh.) trees grew taller during the three study years. They occupied the clear cutting. As a result, the plot was covered in their shade. The shading (50\% of the light on plot a and plot c) resulted in the decrease of the average height, projective cover and number of reproductive shoots of $S$. canadensis. The number of vegetative shoots was higher than the generative ones. This caused a considerable increase in the number of native species at the plot. Thus, $S$. canadensis was less invasive in the shade, while it was a strong competitor in places with sufficient sunlight. This is why it is difficult to prioritise management strategies using species distribution models, which are often used to predict the potential invasive range of introduced species (Suárez-Mota et al., 2016).

Solidago canadensis and Pteridium aquilinum were dominants at plot $\mathrm{c}$ and competed with each other. Under the cover of these dominants, the number of native species declined. Hieracium umbellatum L., Veronica chamaedrys L., Hypericum maculatum Crantz almost completely disappeared, along with such persistent species as Elymus repens and Calamagrostis epigejos (L.) Roth.

At plot a, the Shannon diversity index significantly decreased (from 2.3 to 1.6 ; $\mathrm{t}$ (Student's t) $=2.28$ ). At plot $b$, it significantly increased (from 1.4 to $2.1 ; \mathrm{t}=2.25)$. And at plot $\mathrm{c}$, the Shannon index remained almost unchanged (from 1.8 to $1.6 ; t=0.68)$. Multivariate cluster analysis of the presence/absence of species at the studied plots allowed us to make the dendrogram in Fig. 3. It demonstrates the biodiversity variation from year to year at plot a (AB) and $b(\mathrm{CD})$, and the lack of variation at plot $\mathrm{c}(\mathrm{EF})$. Thus, we demonstrated both trends: implementation success of Solidago canadensis that displaced native species (plot a and c), and instability of $S$. canadensis populations as a result of sunlight deficit (plot b).

The Jaccard index for the studied plots is quite low (Appendix 2). We explain such a low species similarity at the studied plots by the rapid change of vegetation due to invasive species. With the exception of plot $b$, the species richness was reduced by the $S$. canadensis invasion. The same trend was detected for other invasive species in Europe (Hejda et al., 2009).

The $S$. canadensis abundance increased much slower in natural phytocoenoses as compared to abandoned lands. For example, in the southeast of Belarus, $S$. canadensis invaded the plant communities of abandoned agricultural lands at the primary stages of progressive succession, and can cause its inhibition (Gusev, 2015). According to these data, the projective cover of this species increased from $8 \%$ to $60 \%$ during five years (Fig. 4 ), while the projective cover of other species respectively reduced as follows: Calamagrostis epigejos - in 3.8 times; Artemisia vulgaris L. - in 1.8 times; Urtica dioica L. - in 2.0 time, etc. Also the species richness reduced by 10.8 species per $100 \mathrm{~m}^{2}$.

In the southeast of Belarus, the $S$. canadensis occurrence was $2.9 \%$ in forest landscapes, $14.7 \%$ in meadows and pastures, $15.5 \%$ in abandoned lands, $34.3 \%$ in agricultural built-up landscape, and $41.3 \%$ in urbanised landscape (Gusev, 2018). During 10 years, the projective cover of $S$. canadensis at the study plots increased in ten and hundred times. It increased from $8.0 \%$ to $94.0 \%$ at the agricultural plot (AGR), from $0.1 \%$ to $18.0 \%$ at the built-up landscape (BL) and sand pit (SAND) plots, and from $14.0 \%$ to $46.0 \%$ at the ruderal (RUD) plot (Fig. 4). The increase in the projective cover has been accompanied by a biodiversity reduction. For example, in abandoned lands, the total number of species reduced in 2.8 times. And the number of species per $100 \mathrm{~m}^{2}$ reduced in three times (Gusev, 2018). 


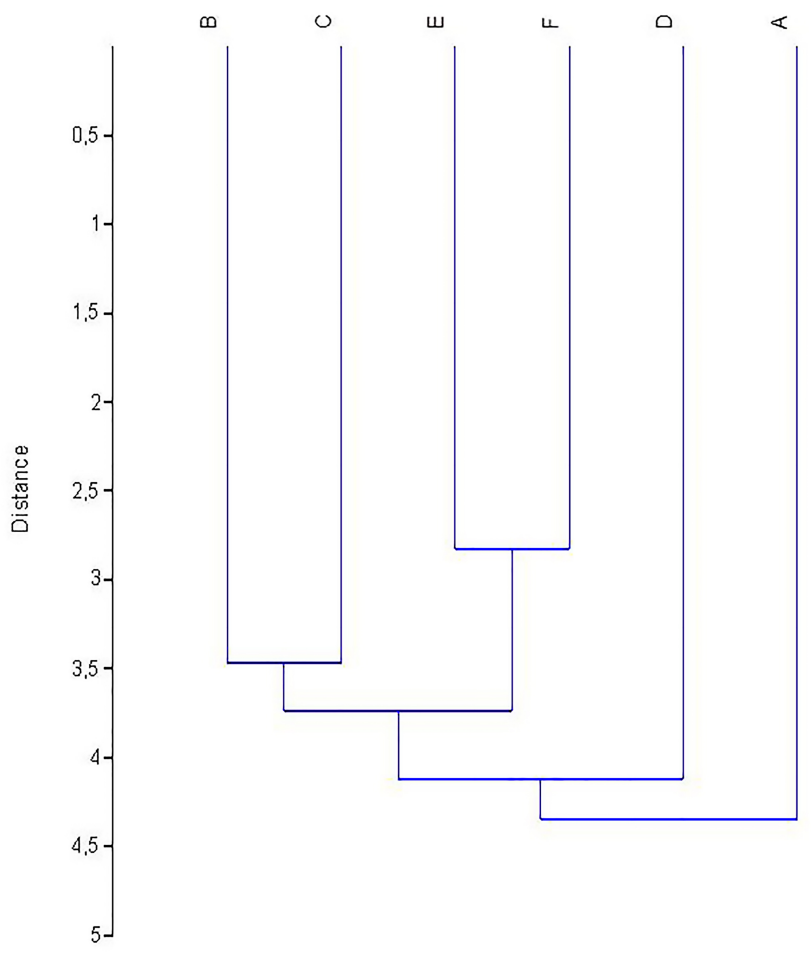

Fig. 3. Multivariate cluster analysis of the species' presence/ absence at the plots in 2016 and 2018. Designations: A - plot a (2016), B - plot a (2018), C - plot b (2016), D - plot b (2018), E - plot c (2016), F - plot c (2018).

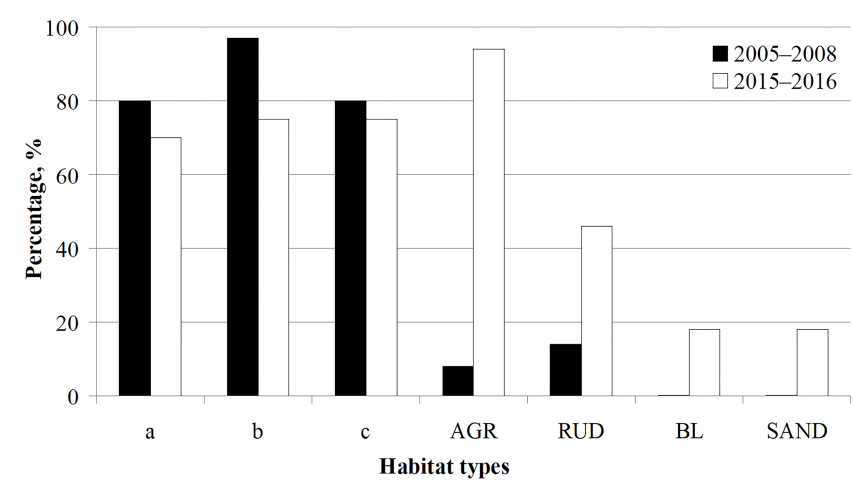

Fig. 4. Projective cover of Solidago canadensis in different habitat types. Designations: a, b, c - natural phytocoenoses of the Sanctuary «Prilepsky» (this study); AGR (agricultural plot), RUD (ruderal plot), BL (built-up landscape), SAND (sand pit plots) (according to Gusev, 2018).

Despite the slower Solidago canadensis invasion in natural plant communities, this process is more dangerous. It can result in the inhibition and even complete extinction of native species, supposed to be preserved within Protected Areas. Gallardo et al. (2017) demonstrated that a quarter of European Protected Areas over the last 100 years have been colonised by invaders. This is even more unacceptable, as the $S$. canadensis invaded a Protected Area, Sanctuary «Prilepsky», where any introduction of non-native organisms must be eradicated.

\section{Conclusions}

As in many other regions, in the Sanctuary «Prilepsky», so far the control of invasive species has been limited to halfway measures. For example, in June 2018 S. canadensis was mowed once nearby the studied plots in the Sanctuary «Prilepsky». Solidago canadensis responded by a massive forming of vegetative shoots. We established that they were able to form the reproductive organs already this year. This fact will only aggravate the impact of $S$. canadensis on the native flora (Fig. 5). Based on the data obtained, we propose planting native tree species, in particular Picea abies (L.) H. Karst. Tree plantations may then create shading in the open areas. This might be one of the long-term control measures for $S$. canadensis in the Sanctuary «Prilepsky». Mowing may be also used. However, it should be carried out several times per year. As an emergency measure we propose direct eradication of Solidago canadensis (with underground organs) by volunteers.

The Solidago canadensis invasiveness largely depends on the sunlight amount in a habitat. The number of native species in a plant community declines in conditions of the absence of control measures and with sufficient sunlight. At the same time, in shaded habitats, the competitiveness of $S$. canadensis is not so high. And the species richness of plant communities at the sample plots has increased from year to year. The native plants are outcompeted more rapidly under impact of multiple alien species invading native phytocoenoses at the same time.

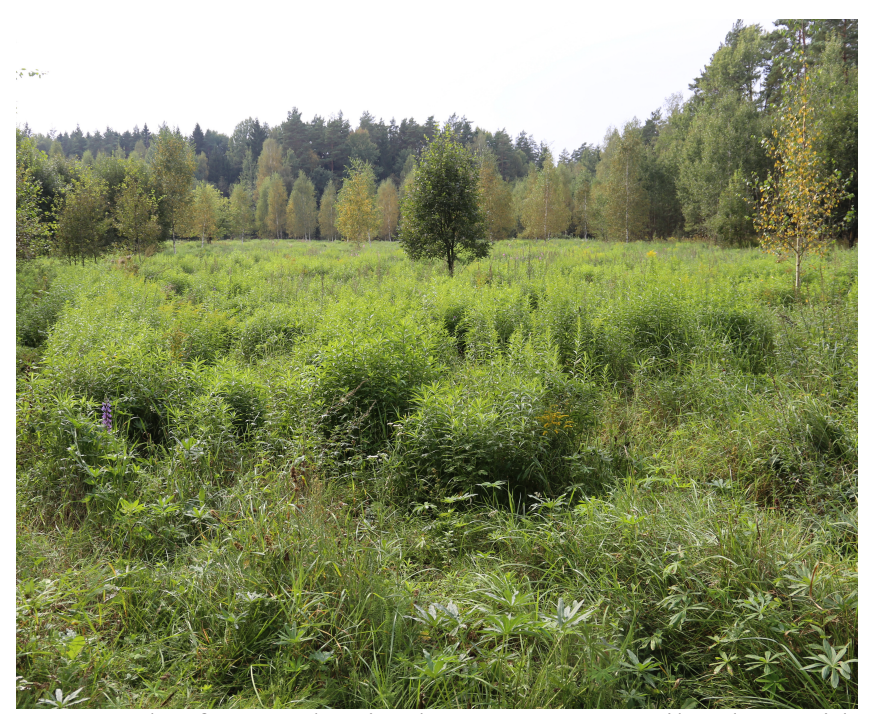

Fig. 5. The forest edge in the Sanctuary «Prilepsky» with vegetative shoots of Solidago canadensis after its single mowing in June (Photo made 05.09.2018). 
According to the European Community legislation, the objectives of Protected Areas include the prevention, minimisation and mitigation of the negative impact of both intentionally and unintentionally introduced alien species on biodiversity status (Regulation (EU) 1143/2014). However, mowing once a year is ineffective in terms of controlling the Solidago canadensis invasion. We propose to control $S$. canadensis by planting native tree species at the open parts of the Sanctuary «Prilepsky», multiple mowing, and direct eradication of $S$. canadensis plants at the areas of most concern (for example, in habitats occupied by threatened native species).

\section{Acknowledgements}

The study has been carried out in accordance with the Main Botanical Garden of RAS (Research Project No. 118021490111-5) and partly supported by the Russian Foundation for Basic Research (grant 18-04-00411). We are grateful to the anonymous reviewers who helped to improve the original version of this manuscript.

\section{References}

Arends G. 1951. Mein Leben als Gärtner und Züchter. Stuttgart: Ulmer. 98 p.

Belt J., LaFleur D., Sladek M. 2011. Invasive Plants of the Crown of the Continent. Crown Managers Partnership. $116 \mathrm{p}$.

Dubovik D.V., Saulov A.O. 2017. North American species of the genus Solidago L. (Asteraceae) in the flora of Belarus. Botany (Research): Scientific Works 46: 18-26. [In Russian]

Dubovik D.V., Skuratovich A.N., Tretyakov D.I. 2013. New alien plant species for Belarus and Europe. Botany (Research): Scientific Works 42: 3-28. [In Russian]

Dubovik D.V., Lebedko V.N., Parfenov V.I., Savchuk S.S., Skuratovich A.N. 2017. The plants - aggressors. Invasive species on the territory of Belarus. Minsk: Belarusian Encyclopedia. 192 p. [In Russian]

Foxcroft L.C., Rouget M., Richardson D.M. 2007. Risk Assessment of Riparian Plant Invasions into Protected Areas. Conservation Biology 21(2): 412-421. DOI: 10.1111/j.1523-1739.2007.00673.x

Foxcroft L.C., Pyšek P., Richardson D.M., Genovesi P. (Eds.). 2013. Plant invasions in protected areas: patterns, problems and challenges. Dordrecht: Springer. 656 p. DOI: 10.1007/978-94-007-7750-7

Gallardo B., Aldridge D.C., González-Moreno P., Pergl J., Pizarro M., Pyšek P., Thuiller W., Yesson Ch., Vilà M. 2017. Protected areas offer refuge from invasive species spreading under climate change. Global Change Biology 23(12): 5331-5343. DOI: $10.1111 /$ gcb.13798

Gusev A.P. 2015. Impact of invasion of Canadian goldenrod (Solidago canadensis L.) on restorative succession in abandoned lands (southeast of Belarus). Russian Journal of Biological Invasions 6(2): 74-77. DOI: 10.1134/S2075111715020034

Gusev A.P. 2018. The invasion of Canadian Goldenrod (Solidago canadensis L.) in anthropogenic landscapes of
Belarus. Russian Journal of Biological Invasions 9(1): 22-28. DOI: 10.1134/S2075111718010083

Hejda M., Pyšek P., Jarosík V. 2009. Impact of invasive plants on the species richness, diversity and composition of invaded communities. Journal of Ecology 97(3): 393-403. DOI: 10.1111/j.1365-2745.2009.01480.x

Index plantarum in horto Adamowiano Letce-Wielkie (Rossiae Occident. prov. Witebsk) crescentium nec circa eum partium in loco natali lectarum pro voluntaria reciproca permutatione. Offertis, $1915.39 \mathrm{p}$

Kozlovskaya N.V. 1978. Alien and progressive species in the flora of Belarus. Botany (Research): Scientific Works 20: 88-95. [In Russian]

Monaco A., Genovesi P. 2014. European Guidelines on Protected Areas and Invasive Alien Species. Strasbourg: Council of Europe - Lazio Region, Rome: Regional Parks Agency. 58 p.

Nagendra H., Lucas R., Pradinho Honrado J., Jongman R.H.G., Tarantino C., Adamo M., Mairota P. 2013. Remote sensing for conservation monitoring: Assessing protected areas, habitat extent, habitat condition, species diversity, and threats. Ecological Indicators 33: 45-59. DOI: 10.1016/j.ecolind.2012.09.014

NOBANIS. 2018. Invasive Alien Species Fact Sheet Solidago canadensis. Available from https://www.nobanis.org (Accessed: 06.11.2018).

Pauchard A., Alaback P.B. 2004. Influence of Elevation, Land Use, and Landscape Context on Patterns of Alien Plant Invasions along Roadsides in Protected Areas of South-Central Chile. Conservation Biology 18(1): 238 248. DOI: 10.1111/j.1523-1739.2004.00300.x

Regulation (EU) 1143/2014. Regulation (EU) No $1143 / 2014$ of the European Parliament and of the Council of 22 October 2014 on the prevention and management of the introduction and spread of invasive alien species. Available from http://data.europa. eu/eli/reg/2014/1143/oj (Accessed: 21.12.2018).

Scherer-Lorenzen M., Venterink H.O., Buschmann H. 2008. Nitrogen Enrichment and Plant Invasions: the Importance of Nitrogen-Fixing Plants and Anthropogenic Eutrophication. In: W. Nentwig (Eds.): Biological Invasions. Ecological Studies (Analysis and Synthesis). Vol. 193. Berlin, Heidelberg: Springer. P. 163-180. DOI: 10.1007/978-3-540-36920-2_10

Sell P., Murrell G. 2006. Solidago L. In: P. Sell, G. Murrell (Eds.): Flora of Great Britain and Ireland, Vol. 4. Campanulaceae - Asteraceae. Cambridge: Cambridge University Press. P. 440-443.

Semple J.C., Faheemuddin H., Chong Y.A., Sorour M.K., Hood J.A., Khamis I., Ma.Y., Kornobis K. 2013. A multivariate morphometric study of the Solidago canadensis / S. lepida complex of Solidago subsect. Triplinerviae. I. Northeastern taxa (Asteraceae: Astereae). Phytoneuron 58: 1-20.

Semple J.C., Rahman H., Bzovsky S., Sorour M.K., Kornobis K., Laphitz R.L., Tong L. 2015. A multivariate morphometric study of the Solidago altissima complex and S. canadensis (Asteraceae: Astereae). Phytoneuron 10: 1-31.

Semple J.C., Cook R.E. 2006. Solidago. In: Flora of North America. Vol. 20. P. 107-166. 
Shishkin B.K. (Ed.). 1959. Flora of the Belorussian Soviet Socialist Republic. Vol. 5. Minsk: Publishing House of the Academy of Sciences of the BSSR. 267 p. [In Russian]

Suárez-Mota M.E., Ortiz E., Villaseñor J.L., Espinosa-García F.J. 2016. Ecological Niche Modeling of Invasive Plant Species According to Invasion Status and Management Needs: The Case of Chromolaena odorata (Asteraceae) in South Africa. Polish Journal of Ecology 64(3): 369. DOI: 10.3161/15052249PJE2016.64.3.007

The Main Book on the Plant Introduction of the CBG NAS of Belarus №1. 1948. 15.02.1947-17.02.1948. [In Russian]

Tilt W. 2015. Flora of the Yellowstone. A guide to the wildflowers, shrubs, trees, ferns and grass-like plants of the Greater Yellowstone Region of Idaho, Montana, and Wyoming. Montana: Gallatin Valley Land Trust. 404 p.

Verloove F., Zonneveld B.J.M., Semple J.C. 2017. First evidence for the presence of invasive Solidago altissima (Asteraceae) in Europe. Willdenowia 47(1): 69-75. DOI: $10.3372 /$ wi.47.47107
Vinogradova Yu. 2018. Theory and practice of the natural biodiversity conservation. In: Second International Conference "Systematic and Floristic Studies of Northern Eurasia devoted to the $90^{\text {th }}$ anniversary of the birth of Prof. A.G. Yelenevsky» (5-8 December 2018). Moscow. Vol. 1. P. 140-143. [In Russian]

Vinogradova Yu., Galkina M. 2019. Hybridization as a factor of invasive activity of alien Solidago species. Zhurnal Obshchei Biologii 80(1): 43-56. DOI: 10.1134/ S004445961901007X [In Russian]

Weber E. 1998. The dynamics of plant invasions: a case study of three exotic goldenrod species (Solidago L.) in Europe. Journal of Biogeography 25(1): 147-154. DOI: 10.1046/j.1365-2699.1998.251119.x

Weber E. 2001. Current and Potential Ranges of Three Exotic Goldenrods (Solidago) in Europe. Conservation Biology 15(1): 122-128. DOI: 10.1111/j.1523-1739.2001.99424.x

Wyoming Weed and Pest Council. 2018. Wyoming Weed \& Pest Control Act Designated List. Available from: http://www.wyoweed.org (Accessed: 09.11.2018).

Appendix 1. Changing the set of associated species and their projective cover on the studied plots in years of study.

\begin{tabular}{|c|c|}
\hline 2016 & 2018 \\
\hline \multicolumn{2}{|c|}{ Plot a: Lupinus polyphyllus + Festuca rubra + Solidago canadensis community } \\
\hline 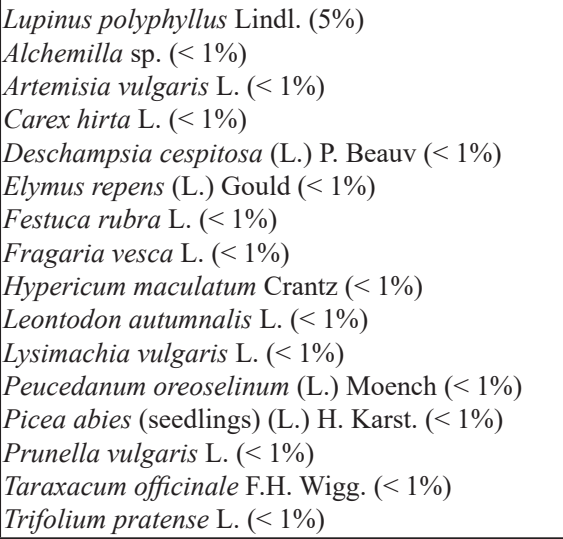 & $\begin{array}{l}\text { Festuca rubra L. }(80 \%) \\
\text { Lupinus polyphyllus Lindl. (15\%) } \\
\text { Deschampsia cespitosa }(\mathrm{L} .) \text { P. Beauv }(10 \%) \\
\text { Populus tremula L. (seedlings) (3\%) } \\
\text { Agrostis tenuis Sibth. (2\%) } \\
\text { Hypericum maculatum Crantz (2\%) } \\
\text { Ranunculus repens L. (1\%) } \\
\text { Stellaria graminea L. (1\%) }\end{array}$ \\
\hline \multicolumn{2}{|c|}{ Plot b: Elymus repens + motley grasses + Solidago canadensis community } \\
\hline $\begin{array}{l}\text { Elymus repens }(\mathrm{L} .) \text { Gould }(70 \%) \\
\text { Chamerion angustifolium }(\mathrm{L} .) \text { Holub }(5 \%) \\
\text { Lupinus polyphyllus Lindl. (1\%) } \\
\text { Artemisia vulgaris L. }(<1 \%) \\
\text { Peucedanum oreoselinum }(\mathrm{L} .) \text { Moench }(<1 \%) \\
\text { Urtica dioica } \mathrm{L} .(<1 \%)\end{array}$ & $\begin{array}{l}\text { Knautia arvensis (L.) J.M. Coult. (7\%) } \\
\text { Agrostis tenuis Sibth. (4\%) } \\
\text { Lupinus polyphyllus Lindl. (4\%) } \\
\text { Ajuga reptans L. (3\%) } \\
\text { Prunella vulgaris L. (3\%) } \\
\text { Ranunculus repens L. (3\%) } \\
\text { Oxalis acetosella L. (2\%) } \\
\text { Veronica chamaedrys L. (2\%) } \\
\text { Athyrium filix-femina (L.) Roth (1\%) } \\
\text { Fragaria vesca L. (1\%) } \\
\text { Hypericum maculatum Crantz (1\%) } \\
\text { Lysimachia vulgaris L. (1\%) } \\
\text { Viola riviniana Rchb. (1\%) }\end{array}$ \\
\hline \multicolumn{2}{|c|}{ Plot c: Solidago canadensis + Pteridium aquilinum community } \\
\hline $\begin{array}{l}\text { Pteridium aquilinum }(\mathrm{L} .) \text { Kuhn }(60 \%) \\
\text { Elymus repens }(\mathrm{L} .) \text { Gould }(60 \%) \\
\text { Agrostis tenuis Sibth. }(<1 \%) \\
\text { Hieracium umbellatum } \mathrm{L} .(<1 \%) \\
\text { Solidago virgaurea } \mathrm{L} .(<1 \%) \\
\text { Rubus idaeus } \text { L. }(<1 \%) \\
\text { Veronica chamaedrys } \mathrm{L} .(<1 \%) \\
\text { Hypericum maculatum } \text { Crantz }(<1 \%) \\
\text { Maianthemum bifolium } \text { (L.) F.W. Schmidt }(<1 \%) \\
\text { Calamagrostis epigeios }(\mathrm{L} .) \text { Roth }(<1 \%)\end{array}$ & $\begin{array}{l}\text { Pteridium aquilinum (L.) Kuhn (45\%) } \\
\text { Agrostis tenuis Sibth. (7\%) } \\
\text { Festuca rubra L. (3\%) } \\
\text { Sambucus racemosa } \text { L. (3\%) } \\
\text { Frangula alnus Mill. (1\%) } \\
\text { Maianthemum bifolium (L.) F.W. Schmidt (1\%) } \\
\text { Rubus idaeus L. (1\%) } \\
\text { Solidago virgaurea L. (1\%) }\end{array}$ \\
\hline
\end{tabular}


Appendix 2. Jaccard index for studied plots (\%).

\begin{tabular}{|c|c|c|c|c|cc|c|}
\hline & $\mathrm{a}(2016)$ & $\mathrm{a}(2018)$ & $\mathrm{b}(2016)$ & $\mathrm{b}(2018)$ & $\mathrm{c}(2016)$ & $\mathrm{c}(2018)$ \\
\hline $\mathrm{a}(2016)$ & 100.0 & 15.4 & 20.8 & 19.4 & 10.7 & 7.7 \\
\hline $\mathrm{a}(2018)$ & & 100.0 & 12.5 & 17.4 & 10.0 & 16.7 \\
\hline $\mathrm{b}(2016)$ & & & 100.0 & 9.5 & 11.1 & 6.3 \\
\hline $\mathrm{b}(2018)$ & & & & 100.0 & 16.0 & 8.7 \\
\hline $\mathrm{c}(2016)$ & & & & & 100.0 & 30.0 \\
\hline $\mathrm{c}(2018)$ & & & & & & 100.0 \\
\hline
\end{tabular}

Note: Types of plant communities: a) Lupinus polyphyllus + Festuca rubra + Solidago canadensis community b) Elymus repens + motley grasses + Solidago canadensis community, c) Solidago canadensis + Pteridium aquilinum community.

\title{
ИНВАЗИОННАЯ АКТИВНОСТЬ SOLIDAGO CANADENSIS НА ТЕРРИТОРИИ ЗАКАЗНИКА «ПРИЛЕПСКИЙ» (БЕЛАРУСЬ)
}

\author{
Д. В. Дубовик $\kappa^{1, *}$ А. Н. Скуратович' ${ }^{1}$ Д. Миллер ${ }^{2}$, Е. В. \\ Спиридович ${ }^{3}$ Ю. Н. Горбунов ${ }^{4}$ Ю. К. Виноградова ${ }^{4, * *}$ \\ ${ }^{1}$ Институт экспериментальной ботаники имени В.Ф. Купревича НАН Беларуси, Беларусь \\ *e-mail:dvdubovik73@gmail.com \\ ${ }^{2}$ Ландтафтный дендрарий Университета Миннесоты, США \\ e-mail:mille414@umn.edu \\ ${ }^{3}$ Центральный ботанический сад НАН Беларуси, Беларусь \\ e-mail:E.Spiridovich@cbg.org.by \\ ${ }^{4}$ Главный ботанический сад РАН, Россия \\ **e-mail:gbsad@mail.ru
}

\begin{abstract}
Особо охраняемые природные территории предоставляют ценную информацию относительно воздействия инвазионных чужеземных видов на естественное биоразнообразие и функционирование экосистем, а также о динамике инвазионного процесса. Solidago canadensis является одним из самых агрессивных чужеземных растений, который входит в первую сотню наиболее опасных инвазионных видов мира. Целью настоящего исследования был мониторинг внедрения S. canadensis в фитоценозы заказника «Прилепский», расположенного в окрестностях г. Минска (Беларусь). Нами кратко описана история интродукции Solidago canadensis в Европе и детально - на территории Беларуси. В 2016 г. и 2018 г. исследовали параметры растений, по которым можно судить об успешной натурализации вида. Среди них - средняя высота побегов, проективное покрытие, среднее число генеративных и вегетативных побегов и число сопутствующих видов на учетных площадях. Площади размером $1 \times 1$ м были заложены в трех повторностях в трех фитоценозах заказника «Прилепский». Отмечено, что инвазионная активность $S$. canadensis зависит от степени освещенности местообитаний, при дефиците которой инвазивность вида снижается. Ранее в заказнике «Прилепский» в качестве меры борьбы с золотарником канадским применяли однократное кошение. Однако это, напротив, привело к разрастанию популяций инвазионного вида. Предложено начать облесение открытых участков заказника «Прилепский» местными древесными породами (например, Picea abies) с применением многократного кошения, а также прямого уничтожения Solidago canadensis силами волонтеров.
\end{abstract}

Ключевые слова: биоразнообразие, золотарник канадский, инвазия, ООПТ, растительное сообщество 